\title{
Environmental Performance on Environmental Disclosure and Financial Performance: Evidence From Indonesia
}

\author{
$1^{\text {st }}$ Desi Risma Sari \\ Accounting Department \\ Faculty of Economic and Business \\ Universitas Dian Nuswantoro \\ Semarang, Indonesia \\ desirismasari88@gmail.com
}

\author{
$2^{\text {nd }}$ Anna Sumaryati \\ Accounting Department \\ Faculty of Economic and Business \\ Universitas Dian Nuswantoro \\ Semarang, Indonesia \\ anna.sumaryati@dsn.dinus.ac.id
}

\begin{abstract}
This study aims to examine the effect of environmental performance on environmental disclosure and financial performance. The population in this study are companies listed on the Indonesia Stock Exchange (IDX) in 2010-2017. This research sample uses a purposive sampling method. Based on the purposive sampling method, with criteria 1) mining companies that issue financial statements. 2) mining companies that follow PROPER. 3) mining companies that issue environmental disclosures in Sustainability Reporting, the number of sample companies is $\mathbf{4 2}$ companies. Simple linear regression analysis method with the application of SPSS version 20 (Statistical Product and Service Solutions). The results of this study indicate that 1) environmental performance has a significant effect on environmental disclosure. These results can be concluded that the higher the level of PROPER, the higher the desire of companies to make environmental disclosures. 2) environmental performance has a significant effect on financial performance. These results can be concluded that when a company with good environmental performance will get a good response from the stakeholders and also have an impact on the long-term increase in company revenue.
\end{abstract}

Keywords-environmental performance, environmental disclosure and financial performance

\section{INTRODUCTION}

In the era of economic globalization, and corporate responsibility corporate goals began to shift from the focus of profit, to companies that care about the environment and social. Industry is a figure in a trading activity, dreaming of being able to successfully grow rapidly for the sake of encouraging (economic) trade growth. The existence of a company will bring a fresh breeze for an area that is used as a place of company management. The existence of a company in a region can be seen by its human resources is the opening of employment opportunities for the surrounding community, technological advances, infrastructure development, development of good communication facilities, local tax revenue from the existence of mining companies in the area. However, the company's growth is not far from the negative impacts that will be concluded.

Looking at the economic side indicators, in addition, an increasing number of companies are also contributors to environmental damage, from an environmental perspective.
Handling can be achieved by anticipating the impact of the industry on the social environment that is the company in anticipation of the company's activities on the environment through an activity of corporate social responsibility and environmental responsibility [3]

The tragedy of environmental damage due to company activities such as the case of good environmental management is PT Freeport Indonesia. According to WALHI (Indonesian Life Environment Organization) Reported water pollution that occurred in West Papua, caused by the slaughter of added waste by PT Freeport Indonesia in the form of rocks and liquids that have the potential to cause pollution of the Aghawagon, Autonomous and Ajkwa rivers which empties into the Araffur Sea. The impact of PT Freeport Indonesia's waste caused damage to the ecosystem around the mining area and harmed the damage to the ecosystem around the mine area, as well as harming the surrounding community who could not utilize water from the Autonomous Aghawagon River and Ajkwa which were contaminated with waste [19]

Environmental performance is a company performance that cares about the environment around the company (industry). Environmental performance is assessed in company (industry) presentations that participate in the Company Performance Rating Assessment Program in Environmental Management (PROPER). PROPER will be notified to the public every year, with that the company will increase reputation, depending on the companies participating in PROPER obeying the rules. Environmental performance on environmental disclosure is the theory of legitimacy, it is said that every company is aware of social and environmental problems is a form of responsibility in the survival of the company. The results of research that have been conducted, found research results from [13] show the results that environmental performance influences environmental disclosure, as well as research on [14] [12] shows environmental result performance effect the environmental disclosure. However, the research of [10] shows different results, namely the environmental performance variable does not affect environmental disclosure.

Environmental disclosure is disclosed in an information related to the environment and social in the company's 
annual report. use the Global Reporting Initiative or GRI G4 [9] As part of the company's social environmental regulations it is better to report information on managing the company's social environment in the annual report. Financial performance is expressed in a company's annual report. Increasing competitiveness can be achieved through accuracy of planning, identifying needs by considering changing environmental conditions. Corporate financial ratios (industry) is a reflection of a company's performance is an analysis in which to determine the condition of a company (industry). Financial performance is implemented from industrial activities as an interaction between stakeholders, thus all activities must meet stakeholder approval. Good environmental performance is a reflection of the company in carrying out its performance and is also good news for the company which means that high environmental performance will be responded positively by investors through shareholders and is based on a long-term increase for the company in revenue which is a reflection of the achievement of company performance. Social and environmental care are factors that affect financial performance. Concern for the environment arises due to encouragement from outsiders including: government, stakeholders, shareholders [12] [4] that environmental performance variables influence financial performance. However, research conducted by [18] shows different results, namely environmental performance variables does not affect financial performance variables. This research was conducted on mining companies listed on the Indonesia Stock Exchange (IDX) that were selected for the basis of the study because based on the phenomena that occurred related to the company there were deviations in the management of social responsibility towards the environment against environmental damage. Based on the background above, the researcher will examine: 1]. does environmental performance have an influence on environmental disclosure? 2]. does environmental performance have an influence on financial performance? While the aim of this study is to determine whether environmental performance has an influence on environmental disclosure and financial performance.

\section{LITERATURE REVIEW AND HYPOTHESIS DEVELOPMENT}

This research uses Legitimacy theory because this theory is based on, companies must participate in social and environmental activities that have accounting implications on reporting and disclosure in company annual reports through published social and environmental reporting [5][6] Legitimacy theory is a theory in gaining public trust from company activities carried out, thus the company (industry) in carrying out social and environmental activities with norms and values applicable to the community. Environmental Performance.

Environmental performance is a company's environmental performance that cares about its concern for the surrounding environment. Environmental performance is carried out by companies for their responsibility to the environment. According to [11] environmental performance, namely the state of the company's performance to participate in preserving the environment. Environmental is information from companies in the annual report relating to the social and environmental aspects of the report and each period must be disclosed [17] [7].. Environmental disclosure as a collection of information relating to environmental management activities by companies past, present and or future. Information can be obtained by means of qualitative statements, assertions or quantitative facts, forms of financial statements.

Financial performance is an art that is difficult to measure with exact or more to the subjective and objective aspects of writing. According to [2] financial performance is a benchmark for making decisions in strategy, apart from that many ways must be taken so that in the analysis of financial performance can be done. The measurement of financial performance that is used to determine the profitability of a company or the income earned by a company is to use the ROA benchmark

Effect of environmental performance on environmental disclosure Companies (industries) that have good environmental performance will report environmental disclosures by themselves. This is indicated by the fact that there is a party to the interest in the company in carrying out its environmental responsibilities well. Legitimacy theory provides an insight into the importance of environmental responsibility by industry. The existence of environmental disclosure carried out by the industry also increases public confidence in the company, giving rise to a good image for the company. [13] [14] found environmental performance to determine the effect on environmental disclosure, both studies stated that environmental performance has a significant effect on environmental disclosure. This is due to the voluntary disclosure that is applied, so companies whose environmental performance is said to be bad will tend to hide their environmental disclosures, while according to [15] which states the same result that extensive environmental disclosure is influenced by good environmental performance as well. Based on the description above, the hypotheses that are:

H1: Environmental Performance Influences Environmental Disclosure The effect of environmental performance on financial performance.

Companies that have good environmental performance will be responded positively by investors through stakeholders and will also contribute to the long-term increase in company revenue. Conversely, if the company (industry) has a bad environmental performance, investors will doubt about the company and respond negatively with income that decreases (loss) from period to period. Thus the environmental disclosure of mining companies going public on the IDX is assessed where companies (industries) that have a very high risk when viewed. The greater the company's role in environmental activities, the better the positive image for stakeholders. Then it can attract the attention of stakeholders and the public users of financial statements. With the improved environmental performance of the company the better the financial performance of the company. The impact is an increase in corporate income which is relatively a reflection of the achievement of financial performance. [12] show that environmental performance variables significantly influence financial performance. This is also supported by the research of [4] that the presence of companies following PROPER can increase stakeholder confidence in taking an investment attitude, so as to encourage good economic performance for the company. Based on the description above, the hypotheses that are:

$\mathrm{H} 2$ : Environmental Performance Influences Financial Performance 


\section{RESEARCH METHOD}

Population and Sample. The population in this study are all mining companies in Indonesia. This research sample uses purposive sampling based on judgment (judgment). The sample used by 42 companies during 2010-2017. In this study environmental performance variables can be seen from the PROPER at the Ministry of Environment, environmental disclosure from Sustaianbility Reporting, and financial performance from ICMD 2010-2017. The analysis used is using SPSS [8]. The simple linear regression model proposed by an empirical model is as follows: $\mathrm{ED}=\beta \mathrm{o}+\beta \mathrm{EVP}$.....(1)

$\mathrm{FP}=\beta \mathrm{o}+\beta \mathrm{EVP} \ldots . .(2)$

Information

$\mathrm{ED}=$ Environmnetal Disclosure $\mathrm{FP}=$ Financial Performance $\mathrm{EVP}=$ Environmental $\quad$ Performance $\quad \beta \mathrm{o}=$ Constant $\beta=$ Regression coefficient

After conducting a regression test (test model) then the next hypothesis test is used to determine the effect of the independent variable on the dependent either simultaneously or partially. In this study the hypothesis test was used including the $\mathrm{F}$ test, $\mathrm{t}$ test, and the coefficient of determination test.

\section{RESULT AND DISCUSSION}

Based on the classic assumption test that has been done, the data can be shown by the F test can be as follows:

TABEL 1. TEST F OF ENVIRONMENTAL PERFORMANCE ENVIRONMENTAL DISCLOSURE

\begin{tabular}{|c|c|c|}
\hline Model & F & Sig \\
\hline EP - ED & 5.702 & 0.022 \\
\hline
\end{tabular}

a. Source of data processing with SPSS, 2019

The above results obtained a significance value of 0.022 then sig $F(0.022<0.05)$ thus it can be concluded that simultaneously environmental performance variables affect environmental disclosure.

TABLE 2. F TEST OF ENVIRONMENTAL PERFORMANCE FINANCIAL PERFORMANCE

\begin{tabular}{|c|c|c|}
\hline Model & F & Sig \\
\hline Regression & 11,193 & 0,002 \\
\hline \multicolumn{3}{|c|}{ b. Source of data processing with SPSS, 2019 }
\end{tabular}

The above results obtained a significance value of 0.002 then sig $\mathrm{F}(0.002<0.05)$ thus it can be concluded that simultaneously environmental performance variables affect financial performance.

TABLE 3. COEFFICIENT OF DETERMINATION OF ENVIRONMENTA PERFORMANCE ON ENVIRONMENTAL DISCLOSURE

\begin{tabular}{|c|c|c|}
\hline Model & $\mathrm{R}$ & Adjusted R Square \\
\hline 1 & 0.353 & 0.103 \\
\hline \multicolumn{3}{|c|}{ Source of data processing with SPSS, 2019 }
\end{tabular}

Adjusted R square value is 0.103 which means that the independent variable (environmental performance) can explain the dependent variable (environmental disclosure) of
$10.3 \%$ the rest is explained by other factors that are not observed.

TABLE 4. COEFFICIENT OF DETERMINATION OF ENVIRONMENTAL PERFORMANCE ON FINANCIAL PERFORMANCE

\begin{tabular}{|c|c|c|}
\hline Model & $\mathrm{R}$ & Adjusted R Square \\
\hline 2 & 0.468 & 0.199 \\
\hline
\end{tabular}

From the test results above, the coefficient of determination is shown by Adjusted R square value of 0.199 which means that the independent variable (environmental performance) can explain the dependent variable (financial performance) of $19.9 \%$ the rest is explained by other factors that are not observed. In the high income or profit for the company. The first hypothesis in this study is that environmental performance has a significant effect on environmental disclosures in mining companies listed on the Indonesia Stock Exchange in the period 2010-2017. The results showed that the environmental performance of environmental disclosure with a $t$ count of $2.388>\mathrm{t}$ table 1.685 and a significant value of $0.022<0.05$ so the hypothesis was accepted.

This research shows that environmental performance has an influence on environmental disclosure because to inform or inform all social and environmental activities of the company which is important for shareholders to win information about it. This result is in accordance with research by [15] [14] [13] and [16]. The results of the study, evidenced in the company's data Adaro Energy Tbk has increased environmental performance (PROPER) from 3 or(Blue) to 4 (Green) followed by a decrease in environmental revenue from 0.91 to 0.50 in 2012-2013. and vice versa at Indika Energy Tbk company has decreased the level of environmental performance (PROPER) from 4 (Green) to 2 (Red) followed by an increase in environmental disclosure from 0.71 to 0.88 in 2010-2011. Based on these data the high level of environmental performance is low or environmental disclosure is influenced by the PROPER rating.

The higher the PROPER rating obtained by the company, the greater the desire of the company to make disclosures. In accordance with the theory of legitimacy provides a view of oxthe importance of environmental responsibility by the company. This is because with a better environmental performance, environmental disclosure will also be good, and disclosure of environmental quantity and quality information that is more than the company with an increase if the company performs well environmental performance will be listed in the annual report and sustainability report used by the public In determining investor decisions, the company is considered legitimate and responsible, plus the company gets a high rating from the Ministry of Environment (KLH) through the PROPER program.

This proves that broad environmental disclosure is influenced by good environmental performance. Effect of Environmental Performance on Financial Performance. The second hypothesis in this study is that environmental performance influences the financial performance of mining companies listed on the Indonesia Stock Exchange in the period 2010-2017. The results of this study indicate that environmental performance on financial performance with a tcount of 3.346> t table 1.685 and a significance value of $0.002<0.05$ so that the hypothesis is accepted. This study shows that environmental performance has an influence on environmental finance because with a good environmental 
performance the company will get good respect from shareholders, besides that it will have a high income or profit for the company in the long run. These results are consistent with research conducted by [12] [4] and [10].

The results of the study, evidenced by Bukit Asam.Tbk company data which experienced a consistent environmental performance of 5 (gold) followed by a decline in financial performance from 20.14 to 13.63 in 2013-2014. On the contrary, Indo Tambang Raya Megah. Tbk experienced inconsistency in environmental performance, namely 4 (green), which was then followed by an increase in financial performance from 5.36 to 10.80 in 2015-2016.This research contributes to the most important implications. The theory of legitimacy is a factor in the importance of regulating relationships in the form of social contracts between companies and communities to align corporate values and social values. This finding can be used as a basis for strengthening the existence of the theory of legitimacy [1] namely how to include the public interest in corporate strategy. The theory of legitimacy is able to overcome the differences between companies and society which ultimately maximizes the overall value of the company and the social value itself.

\section{CONCLUSION}

Environmental performance influences environmental discourse on mining companies registered in the Indonesian Stock Exchange in the period 2010-2017. Environmental performance influences environmental disclosure in mining companies registered with the Indonesian Stock Exchange in the period 2010-2017. Based on the conclusions above can be limitations in this study1. There is an element of subjectivity in the assessment of environmental disclosure indices using GRI G4 (Global Reporting Initiative). (2) The research object used is the mining company listed on the Indonesia Stock Exchange, only 42 samples, because there are companies that do not attend PROPER every year. For further research, it is better to increase the research period and expand the measurement method, so that it can be compared between one method with another method.

\section{REFERENCES}

[1] Bouilding, K.E.,1978. Rationally, Legitimacy, Responsibility, Search for New Directions in Business and Society ( E.M Epstein and Vota.ed Santa Monica.CA: Goodyear Publishing.

Brigham, Eugene, F. \& Phillip R. (2004). Intermediate Financial Management, Eight Edition. Thomson.

[2] Carroll. A. B., \& Shabana, K. M. (2010). The business horizon. $34(4)$, 39-48. A Review of concepts, research and pratice. International journal of management reviews. 12(1), 85-105

[3] Damanik, I Gst Agung Bagus Adhi dan I Ketut Yadriyana (2017).Pengaruh Kinerja Lingkungan Pada Kinerja Keuangan dengan Pengungkapan Coporaete Social Responsibility Sebagai Variabel Intervening. E-Jurnal Akuntansi Universitas Udayana.

[4] Deegan, C., \& Rankin, M. (1996). Do Australian companies report environmental news objectively? An analysis of environmental disclosures by firms prosecuted successfully by the Environmental Protection Authority. Accounting, auditing \& accountability journal, 9(2), 50-67

[5] Deegan, C. 2007. Organisational legitimacy as a motive for sustainability reporting. In Sustainability Accounting and Accountability, 1st Edition. 127-149. Ed, J. Unnerman, J. Bebbington, and B.O'Dwayer. New York, NY: Routledge.

[6] Effeline, Nuraini F. (2010. Pengaruh Environmental Performance dan Economic performance (studi pada perusahaan yang terdaftar di
Bei). Fakultas Ekonomi Universitas Diponogoro semarang (Skripsi yang tidak di Publiksikan).

[7] Ghozali, Imam, 2011, Aplikasi Analisis Multivariate Dengan Program SPSS,Edisi ke empat. Badan Penerbit Universitas Diponegoro. Semarang

[8] Global Reporting Initiative (GRI). 2013. "Sustainability Reporting Guidelines, Global Reporting Initiative, London ”.http://www.globalreporting.org. Accessed on December 20, 2015.

[9] Hadi, Nor. 2011. Corporate Social Resonsibility. Yogyakarta: Graha Ilmu.

[10] Handayani, Ari Retno (2010). Pengaruh Environmental Performance Terhadap Economi Performance serta Environmental Performance Terhadap Environmental Disclosure (Studi Empiris pada Perusahaan Manufaktur yang Terdaftar diBursa Efek Indonesia). Skripsi. Fakultas Ekonomi dan Bisnis Universitas Diponogoro, Semarang.

[11] Islahuddin,Mirza dan Rizkan (2017). Pengaruh Environmental Performance dan Environmental Disclosure Terhadap Financial Performance Perusahaan Pertambangan dan Pemegang HPH/HPHTI yang terdafatr diBursa Efek Indonesia. Jurnal.Universitas Syiah Kuala Indonesia.

[12] Kurniawan, Rudi (2017). effect of environmental performance on environmental disclosure of manufacturing stock and plantation companies listed in Indonesia stock exchange. Journal of business. 1(1).

[13] Putra,Dedi.,\&Utami,L.I.,(2018).Pengaruh environmental performance terhadap enivormental disclosure dan economi performance. Jurusan Akuntansi Fakultas Ekonomi \& Bisnis , IIB Darmajaya.

[14] Purnama, Dendi (2018). Analisis Karakteristik perusahaan dan environmental Performance terhadap environmnetal disclosure. Universitas Kuningan jurnal akuntansi.

[15] Rohmah, L. Y., \& Wahyudin, A. (2015). Pengaruh environmental performance terhadap economi performance dengan environmental disclosure sebagai variabel intervening. Jurusan akuntansi, fakultas ekonomi, Universitas Negeri Semarang. Indonesia

[16] Setyaningsih dan Asyik. 2016. Pengaruh Kinerja Lingkungan Terhadap Kinerja Keuangan dengan Corposate Social responsibility Sebagai Pemoderasi. Jurnal Ilmu dan Riset Akuntansi, Vol. 5, No. 4. ISSN: 2460-0585

[17] Vivianita, Alfa (2018). Pengaruh Environmental Performance Terhadap Kinerja Keuangan dengan Corporate Governance sebagai Variabel Pemoderasi (Studi Kasus Perusahaan Tambang yang Terdaftar di Bursa Efek Indonesia Tahun 2014-2016). Jurnal Universitas Semarang.

[18] www.kompasiana.com,2015 